\title{
The relationship between the determinants of executive remuneration in South African state-owned enterprises
}

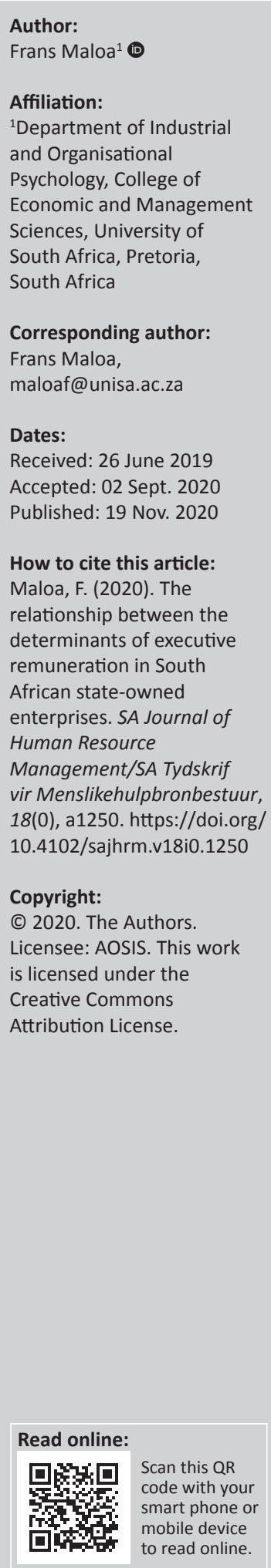

Orientation: Research on executive remuneration should be able to indicate the necessary elements and dimensions at work when deciding on an executive's package.

Research purpose: The purpose of this article was to review a correlation of elements as determinants of executive remuneration.

Motivation for the study: The limited research on executive remuneration tends to focus on how executive pay varies with performance and less on the determinants of executive remuneration.

Research design and method: A quantitative research method was used. The target population consisted of executives from 21 South African state-owned enterprises (SOEs). The research design was a cross-sectional study. A categorical multiple regression analysis was performed.

Main findings: The research results seem to suggest that there is a significant statistical correlation between organisation size and type of industry; job function and type of industry; organisation size and job function; and the level of education and job function as a determinant of executive remuneration within the context of South African SOEs. However, the extent of the correlations between the determinants of executive remuneration is not the same.

Practical/managerial implications: The research results create awareness amongst human resources practitioners and consultants of the extent to which some of the determinants of remuneration may apply in practice.

Contribution/value-add: This study highlights the importance of probing further with the effect of size correlation in quantitative research in the context of executive remuneration.

Keywords: job function; organisation size; industry; level of education; state-owned enterprises.

\section{Introduction}

Executive remuneration has been a sensitive issue for a long time. Researchers have shown a sustained interest in understanding the determinants of executive remuneration (Bullock, Stritch, \& Rainey, 2015; Datta \& Iskandar-Datta, 2014; Pandher \& Currie, 2013), as well as the difference between executive remuneration and employee remuneration (Magnan \& Martin, 2018). Executive remuneration, both in terms of its quantum and the disparity between top and bottom wage earners, has become a major cause of social discontent, fuelling the debate on inequality (IoDSA, 2016). The King IV Report on Corporate Governance recognises that this has become a key governance issue, with major implications for long-term corporate sustainability. However, executives and employees may be paid differently because they perform different types of work and/or have different contractual agreements with the firm (Magnan \& Martin, 2018). Kelynhans (2018) contend that executives, in particular, have duties derived from the common law and the Companies Act 71 of 2008 as amended (the Act), which include honesty, loyalty and good faith. In terms of the Act, the fiduciary duties of executives are not only mandatory and unalterable, but also prescriptive and applicable to all companies. However, Magnan and Martin (2018) argue that the normative principles that define a just pay should be the same for both employees and executives. That is, when reporting on the structure of remuneration paid to employees below the executive level, an organisation should focus on its approach towards fair and responsible pay and its commitment to eliminate all instances of unjustified differentiation between employees doing work that is the same or substantially the same (Green, 2018). Besides, King IV recommends 
that arrangements be provided for in the policy that the remuneration of executive management is fair and responsible in the context of overall employee remuneration (IoDSA, 2016).

However, prior research has focused primarily on the remuneration of the chief executive officer (CEO) leaving out very little knowledge regarding the drivers of remuneration for other executives (Nulla, 2013). Besides, the limited research that has explored issues of executive remuneration tends to focus on how executive pay varies with performance and less on the determinants of executive remuneration (Boivie, Bednar, \& Barker, 2012; Nulla, 2013). Some studies focus on the performance indicators, such as headline earnings per share (HEPS), return on assets (ROAs), return on equity (ROE), earnings before interest tax depreciation and amortisation (EBITDA) and share price, as predictors of executive remuneration (Bussin, 2018; Deysel \& Kruger, 2015; Kirstin \& Du Toit, 2018). However, the predictors of remuneration are all of a financial nature and therefore tend to be endogenous (Kirstin \& Du Toit, 2018). Conversely, Novak and Bilinski (2018) provide a social perspective and assert that the standard determinants of executive remuneration should include controls for managerial skills, employment contract risk, executive characteristics, corporate governance, investor monitoring and political capital.

Although research continues to proliferate, there remains a lack of interdisciplinary consensus regarding the primary forces shaping observable patterns of executive remuneration (Nulla, 2013; Scholtz \& Smit, 2012; Van Essen, Otten, \& Carberry, 2012). Moreover, empirical evidence from scholars has raised doubts about whether there is a 'one-size-fits-all' approach to remuneration (Farid, Conte, \& Lazarus, 2011). Nonetheless, Apanpa and Farimade (2017) contend that for companies that operate in one location or have only one line of business, it is easier to adopt 'a single one-size-fits-all' approach to compensation. However, many organisations carry on businesses from multiple locations across continents or have subsidiaries operating in diverse sectors. These multinationals or conglomerates require even more details in defining their compensation philosophies to ensure alignment between human resources (HR) strategy and peculiar local market and industry practices (Apanpa \& Farimade, 2017).

Meanwhile, executive remuneration remains a controversial topic, especially in South Africa where the wealth gap between the rich and the poor is constantly on the increase (Scholtz \& Smit, 2012). According to the Global Wage Report 2018 and 2019, covering 70 countries and 80\% of wage employees worldwide, South Africa has the world's highest wage inequality with the distribution of wealth between the rich and the poor at a Gini coefficient score of 63.9. As a result, the difference in inequality has seen continued scrutiny of the executive pay by members of the public, consulting firms and the media (Fin24 (2010); KPMG Report, 2010; PwC Report, 2018; Schuitema, 2010).
Executive remuneration within the context of South African state-owned enterprises (SOEs) has also been subjected to scrutiny because SOEs are considered a relevant instrument for the implementation of public policies (Bernier, 2014, 2015; Del Bo \& Florio, 2012; Farmer, Brown, Reilly, \& Bevan, 2013; Millward, 2011; OECD, 2005; Papenfuß \& Schmidt, 2015). Besides, the design of remuneration schemes is a key factor that affects the behaviour and awareness for acting in accordance with the overriding aims of the public authority (Papenfuß \& Schmidt, 2015).

Because executive remuneration has remained a hot debate in South Africa and the rest of the world, further research on the phenomenon remains important. The objective of this research is, therefore, not an examination of how much executives are paid (Fleming \& Schaupp, 2011), but the exploration of the elements that determine the basis of executive remuneration within the context of South African SOEs.

\section{Remuneration guidelines for South African state-owned enterprises}

A remuneration guideline for South African SOEs was established for the first time in 2007, following proposals by the Department of Public Enterprises (DPE) to address issues concerning executive remuneration. The South African SOE remuneration guideline resulted in SOEs categorised into four bands in terms of size and according to asset base and revenue. The model based on market data sourced from a survey conducted in over 600 South African companies suggested an annual guaranteed package for CEOs and executive directors (EDs) in companies that are of the size of SOEs. South African SOEs were categorised as follows:

- Size 1-6: A small organisation categorised as band D.

- Size 7-9: A medium organisation categorised as band C.

- Size 11-12: A large organisation categorised as band B.

- Size 13-16: A very large organisation categorised as band A.

According to the guideline (DPE, 2007), the annual total guaranteed package of CEOs and EDs. should not exceed the median amount of the remuneration model developed by the DPE. State-owned enterprises categorised in bands B-D of the categorisation model should not motivate an offer for a total guaranteed package greater than the median in the band immediately above the one in which the SOE is then located.

Furthermore, the guide states that the board must define a coherent rationale for the remuneration of other executives with the $\mathrm{CEO}$, and that rationale should motivate executives to pursue the long-term growth and success of the company within an appropriate control framework, whilst demonstrating a clear relationship between key executive performance and remuneration. Before implementation, the shareholder must indicate in writing that the 
remuneration of the $\mathrm{CEO}$ and EDs conforms to this guideline. Inflation adjustment increases should not exceed a percentage that is $0.5 \%$ less than the previous year's officially reported rate of inflation. Also, the remuneration of each CEO and ED should be disclosed following the Companies Act, Public Finance Management Act of 1999 (PFMA) and King Code II, at the time. The guideline states that should a board seek to offer an annual guaranteed package that exceeds the median, the chairperson of the board has to seek approval from the shareholder. The chairperson has to prepare a detailed motivation to the shareholder, identifying a clear relationship between the key executive performance and the proposed annual total guaranteed package (South African SOE remuneration guideline, 2007). The motivation has to include information expressing the value of the executive in the following context:

- Impact on the economy.

- Nature of competition.

- Market capitalisation.

- Complexity of industry.

- Strategic freedom to act.

From the guideline, it seems that executive remuneration within the South African SOEs is determined by internal factors, including the size of the organisation, asset base and revenue generated by the enterprise, and external factors, such as the impact on the economy, the nature of the competition and the complexity of the industry.

In 2011, a new model, which would serve as an improvement on the 2007 model, was established. The Minister of Public Enterprises told Parliament's standing committee on public accounts in March 2012 that the freezing of executives' pay increases at all state-owned entities under his department would be in place until a proper remuneration policy was in place Kgosana (2012a).

In 2012, the deputy director general of the DPE presented a progress report on the work that had been conducted by the panel tasked with reviewing executives' pay. Amongst the recommendations was that the size and the asset value of each enterprise should not be taken into consideration when setting executive compensation (Kgosana, 2012). If the recommendations of the panel were accepted, it meant the size and asset value of state-owned companies would not be accepted as a reason for paying executives at larger South African SOEs more than those at smaller South African SOEs. The department was also concerned about South African SOEs benchmarking themselves against Johannesburg Securities Exchange (JSE)-listed companies in terms of executive remuneration when their mandates were different from those of such companies (Kgosana, 2012). Thus, the remuneration guidelines were a strategic plan by the DPE to create a line of sight on how executives within SOEs could be remunerated accordingly towards delivering on the mandate of the government.
Nonetheless, there is not much, if any, written neither on the implementation nor on the evaluation of the revised 2011 guidelines. However, according to Shackleton (2007), the evaluation of strategic plan and performance is normally conducted over a typically 3- to 5-year business cycle. Similarly, according to the framework for strategic plans and annual performance plans (2010) published by the Treasury Department, a strategic plan should cover a period of at least 5 years, ideally from the first planning cycle following an election, linked to the identified outcomes of the Presidency. Although plans may have a longer time frame, they should be revised at least every 5 years, and a new draft or revised strategic plan should generally be prepared for consideration early in the final year of the prior planning period. Also, when budget programme structures are determined, it should be noted that much of what an institution carries out does not change from 1 year to the next; or even from one 5-year planning cycle to the next (National Treasury, 2010).

However, there are two challenges, which relate to the background for and motivation of the current study, namely:

- The revised 2011 guidelines have not been empirically tested 5 years after the implementation.

- Besides, SOEs continue to employ the services of remuneration consultants to advise on executive remuneration in practice.

Nonetheless, there are various determinants and popularly known performance indicators of executive remuneration as mentioned previously (e.g. HEPS, ROAs, ROE and share price), in practice. However, designing executive pay packages is not a simple and straightforward exercise. The practice requires a 'balanced approach' with a wide range of issues. For instance, Carrasco-Hernandez and SánchezMarín (2007) argued that the most suitable compensation design for executives varies according to the type of enterprise. Other researchers have also tried to explain executive pay by consideration for differences in firm size (Conyon \& He, 2011; Fernandes, Ferreira, Matos, \& Murphy, 2013; Gruyter, 2013), the industry (Martocchio, 2011), and the type of job function (Datta Gupta, Poulsen, \& Villeval, 2013). The current study argues that besides the many variables considered in theory and practice, a correlation of some of those popularly used determinants has not been tested empirically, to see how they can improve the process of determining executive remuneration. The contribution of this research is, therefore, unique in that the few chosen elements, namely the organisation size, the type of industry, the job function and the level of education are correlated and statistically interrogated to reveal their significance and the extent to which they determine executive remuneration.

Following the brief background is an overview of the literature framework and hypotheses development, followed by a description of the methodology and the analysis process. 


\section{Theoretical framework}

Given the lack of a generally accepted theory of executive remuneration, commentary in the academic and related literature attempting to theorise executive pay and the contingencies against which it is determined reveals a range of views (Perkins \& White, 2011). Executive remuneration is best explained by a variety of theories that include the popularly referenced principal agency theory (commonly known as agency theory), contingency theory, social comparison theory, structural theory and human capital theory.

The agency theory analyses the relationship that develops in an economic exchange between an employer (the principal) and an employee (the agent), which results in the wealth of the former benefiting from the decisions adopted by the latter (Gomez-Mejia, Berrone, \& Franco-Santos, 2010). Many authors have chosen principal agency theory as their theoretical framework to establish the relations between the employer and the employee in the design of executive compensation reward schemes.

Remuneration also referred to as compensation, or reward, may be defined as 'all forms of financial returns and tangible services and benefits employees receive' (Milkovich \& Newman, 2004, p. 3). Remuneration for the set of employees, who, theoretically, have the highest impact on the effective definition and implementation of an organisation's strategy is usually classified as executive remuneration. Typically, this ends up being the top two layers of an organisation's management hierarchy (Ghose, 2011, p. 9). Similarly, Scholtz and Smit (2012) viewed executive compensation as the total remuneration of EDs of the company as disclosed in published annual reports. This includes directly quantifiable revenue streams as well as unquantifiable benefits, such as surplus utility and satisfaction. Overall, executive remuneration includes the sum of base pay, bonuses, stock grants, stock options, and other forms of compensation and benefits (Bognanno, 2010). However, for the current study, executive remuneration is restricted to the guaranteed pay or fixed component because it is more stable than the variable set by performance targets that may vary and not clearly defined across all organisations.

Nonetheless, empirical evidence from scholars has raised doubt about whether there is a 'one-size-fits-all' approach to remuneration (Farid et al., 2011), and in defining their compensation philosophies to ensure alignment between HR strategy and peculiar local market/industry practices (Apanpa \& Farimade, 2017). In theory, the level of remuneration should be determined upon the analysis of expected value creation by the managers and the decision of the proportion of that value that should be offered to those managers who contributed to generating those effects (Marcinkowska, 2014).
However, to define the concept operationally and break it down to observable and measurable behaviours means that the remuneration should be delineated into dimensions and elements that are measurable. Nevertheless, Gómez-Mejia et al. (2010) contend that:

$[T] \mathrm{o}$ the extent that there are intense interaction and overlap among predictors of executive pay at different levels of analysis, it may be quite difficult, if not impossible, to reliably disentangle the unique effect of one variable from another. (p. 140)

As a result, there seems to be little consensus on the precise nature of the predictors of executive remuneration. It is for the same reason that the current study argues that because there is no one-size-fits-all approach, the determination of executive remuneration can be approached from various angles including investigating the correlations between the elements that have been confirmed in extant theory as the determinants of executive remuneration. Thus, the current study postulates that there is a need to conduct further research in order to understand, in finer terms, the true extent of the relationship between elements of remuneration (Nulla, 2013). The current research intends to test a correlation of various elements that include the organisation size, the type of industry, the job function and the level of education as determinants of executive remuneration within the context of South African SOEs.

\section{Organisation size and type of industry as determinants of executive remuneration}

Organisation size and type of industry as determinants of executive remuneration is best explained by reference to the contingency theory. According to Pugh (1973), 'Contingency theory extends to include any variable that moderates the effect of an organisational characteristic on organisational performance' cited in Trevor (2011, p. 172). Similarly, contextual factors, such as the type of industry and the size of the organisation, are contextually independent variables (IVs) upon which firms' pay practices as a dependent variable (DV) is contingent (Trevor, 2011). Martocchio (2010) also contends that the industry in which an organisation operates influences the pay an executive receives. Similarly, in a study conducted by Bussin (2018), it was found that organisation size plays an influential role in CEO compensation levels in the mining industry. Whilst Agarwal (1981) argued that size is an important determinant of executive compensation because it represents a proxy for organisational complexity. In the same way, organisation size and type of industry, although investigated separately, were also found to be significant determinants of executive compensation within the context of South African SOEs (Maloa \& Bussin, 2016).

Congruently, inferences have been drawn previously between the size of the organisation and the type of industry. For instance, a study conducted by Milkovich, Newman and Gerhart (2014) established that labour-intensive industries, such as education and healthcare, tend to pay lower than technology-intensive industries, such as petroleum or 
pharmaceuticals, whereas professional services pay high. Frydman and Saks (2010) asserted that remuneration should rise along with increases in the size of the typical firm in the market. Similarly, Papenfuß and Schmidt (2015) concluded that the studies of remuneration determinants show that firm size, ownership structure and the market/sector are a key factor in the level, design and development of top management remuneration.

Correspondingly, in most literature findings, remuneration tends to be highly correlated with organisation size, and with firm size measured by the number of employees, and total sales or asset base of the organisation (Bouwman, 2013; Edmans \& Gabaix, 2015; Nourayi \& Daroca, 2008; Nulla, 2013; Sigler, 2011). Therefore, the preferred approach has been to benchmark each role against collected data from a bespoke comparator group, which in turn is determined by the size and industry considerations' (Ebrahimi \& Horak, 2018).

Despite the strong correlation between executive remuneration and the aggregate market value of firms (which may be an indication of size) as documented in recent decades, studies found a much lower correlation of the variables prior to the mid-1970s (Gabaix \& Landier, 2008; Hall \& Murphy, 2003; Jensen, Murphy \& Wruck, 2004). However, in comparison with the more recent decades, strong correlations were found, which may be owing to an upward trend in both variables instead of a causal effect of firm size on pay (Frydman \& Saks, 2010). In view of the foregoing, the hypotheses to be tested are as follows:

H(1): A statistically significant correlation exists between organisation size and the type of industry as a determinant of executive remuneration within the context of South African SOEs.

$\mathbf{H}(2)$ : The extent of the correlation between organisation size and type of industry as a determinant of executive remuneration is the same in the context of South African SOEs.

\section{Job function and type of industry as determinants of executive remuneration}

Job function and type of industry as determinants of executive remuneration is best explained by social comparison theory. Boivie et al. (2012) contend that social comparison research on executive pay is based in large part on principles from equity theory and is at the centre of all compensation theory (Wallace \& Fay, 1983). Whilst much of the social comparison literature focuses on determining what individuals or groups are likely to serve as referents, evidence from CEO compensation literature shows that there are several possible referents individuals can use when making comparisons. To this end, remuneration professionals use regression analysis to establish pay rates for a set of jobs that are consistent with typical pay rates for jobs in the external market (Martocchio, 2010).
However, benchmarking CEO's pay with their peer group has obvious drawbacks. Benchmarking is one of the main reasons that executives' pay rises ever higher (Clifford, 2017). Firstly, using peer group results in determining pay without explicit regard to value creation. Secondly, using peer group has a ratcheting effect. That is, when multiple companies within a group try to meet or exceed the median, the median increases (Larker \& Tayan, 2011; Marcinkowska, 2014; Papenfuß \& Schmidt, 2015).

Similarly, Boivie et al. (2012) state that it is likely that this social comparison process of anchoring executive pay based on readily available and relevant comparison groups will work to push executive compensation higher. Although benchmarking pay is aimed at remaining competitive, paying well below or above the typical market rate for jobs can create a competitive disadvantage for companies (Martocchio, 2010). Every time a CEO gets a generously benchmarked deal, he sets a higher baseline for the next time any leader has pay negotiations (Clifford, 2017). In view of the foregoing, the hypotheses to be tested are as follows:

H(3): A statistically significant correlation exists between job function and type of industry as a determinant of executive remuneration in the context of South African SOEs.

$\mathbf{H}(4)$ : The extent of the correlation between job function and type of industry as a determinant of executive remuneration is the same in the context of South African SOEs.

\section{Organisation size and job function as determinants of executive remuneration}

Organisation size and job function as determinants of executive remuneration are best explained by reference to the structural theory. Defenders of structural theory argue that executive compensation is a direct function of the number of organisational levels. Gomez-Mejia et al. (2010) state that other things being equal, the taller the organisational structure, the greater the earnings of top executives. The best known rationale for this theory was provided by Simon (1957) who argued that 'organisations attempt to maintain appropriate salary differentials between management levels and establish these differentials, not in absolute terms, but as ratios' (cited in Gomez-Mejia et al., 2010, p. 134). In a manner somewhat akin to traditional economic models, the structural perspective is very deterministic, with the earnings of executives being mechanically established as a function of the number of levels below them and a fixed percentage difference between their pay and that of their subordinates.

According to the literature on executive remuneration, it tends to be highly correlated with organisation size. For example, according to Milkovich et. al. (2014), 'there is consistent evidence that large organisations tend to pay more than small ones' (p. 226), presumably, because it requires greater skill to manage a larger complex company with higher growth prospects (Bouwman, 2013). Similarly, Hijazi and Bhatti (2007) contend that the link between executive pay and company size is not surprising given that a larger 
organisation is associated with greater responsibility, expected to be rewarded more.

On the other hand, job function refers to the work content and its value (Milkovich et al., 2014). Work content refers to the work performed in a job and how it is carried out (tasks, behaviour and knowledge required), whilst value refers to the worth of the work: its relative contribution to the organisation objectives (Milkovich et al., 2014). For remuneration purposes, job function is by functional groups, for example, finance, information technology (IT) or personnel, or by work categories, such as administration or customer services, or by occupation, for example, scientists and IT specialists (Armstrong \& Brown, 2001; Incomes Data Services, 2006b). Similarly, jobs of similar complexity at each organisational level combine in the same salary band according to the functional job and experience requirements for each position (IoDSA, 2018). This approach of using job function in remuneration is likely to figure where management believes that different occupations require different reward and career development practices (Armstrong \& Brown, 2001). Given the background, the hypotheses to be tested are as follows:

H(5): A statistically significant correlation exists between the organisation size and job function as a determinant of executive remuneration in the context of South African SOEs.

$\mathbf{H ( 6 ) : ~ T h e ~ e x t e n t ~ o f ~ t h e ~ c o r r e l a t i o n ~ b e t w e e n ~ t h e ~ o r g a n i s a t i o n ~ s i z e ~}$ and job function as a determinant of executive remuneration is the same in the context of South African SOEs.

\section{Level of education and job function as determinants of executive remuneration}

The level of education and job function as determinants of executive remuneration is best explained by reference to human capital theory. According to human capital theory, the acquisition of education increases knowledge and skills, which in turn leads to higher remuneration and personal rewards (Becker, 1964; Greve, Benassi, \& Sti, 2010; Ng \& Feldman, 2010; Strober, 1990). Amongst the many determinants of remuneration, human capital (e.g. education and work experience) is robustly and consistently related to salary level, the number of promotions, the number of job offers and the number of developmental opportunities (Ng \& Feldman, 2010). According to the human capital perspective, accumulation of skills and knowledge gained through education and experience is a key element of executive compensation (Sun, Zhao, \& Yang, 2010). Also, according to Staff writer (2017), Statistics South Africa and Analytico data show that there is graduation in monthly salary the more educated someone is, which highlights the urgency in maintaining a high level of education, as well as addressing crises, such as the staggering drop-out rate experienced in the country. Similarly, $\mathrm{Ng}$ and Feldman (2010) state that the labour market rewards individuals for acquiring more human capital with access to better jobs, higher earnings and incentives to stay.

Researchers typically use 'educated employees' to refer to those individuals who hold at least bachelor's degrees, which are generally necessary for entry into higher paying occupations and organisations (Howard, 1986; Ng \& Feldman, 2010; Trusty \& Niles, 2004). Chief executive officers are interested in leveraging their human capital to maximise remuneration (Geletkanycz, Boyd, \& Finkelstein, 2001; Pandher \& Currie, 2013; Peng, Sun, \& Markóczy, 2014). Consequently, organisations typically have to pay highly competitive wages to hire well-educated employees with considerable work experience (Myers, Griffith, \& Daugherty, 2004). According to Staff writer (2017), tertiary education proves to be the key, with even a tertiary certificate resulting in a $67 \%$ jump in potential earnings, whilst a bachelor's degree would see a $330 \%$ jump. In view of the foregoing, the hypotheses to be tested are as follows:

H(7): A statistically significant correlation exists between the level of education and job function as a determinant of executive remuneration in the context of South African SOEs.

$\mathbf{H ( 8 ) : ~ T h e ~ e x t e n t ~ o f ~ t h e ~ c o r r e l a t i o n ~ b e t w e e n ~ t h e ~ l e v e l ~ o f ~ e d u c a t i o n ~}$ and job function as a determinant of executive remuneration is the same in the context of South African SOEs.

Against the aforementioned literature framework and hypotheses, it is anticipated that the correlations between the elements as hypothesised would create a common criterion according to which executive remuneration could be determined in the context of South African SOEs. The methodology adopted for this study is presented next.

\section{Research design}

The study was both a descriptive and an explanatory research in which empirical research gathered quantitative data. The objective of descriptive research is to gain an accurate profile of events, persons or situations. The emphasis of explanatory research is on studying a problem to explain the relationship between variables (Saunders et al., 2012). In other words, the current study was a descriptive-explanatory study (Saunders, Lewis, Thornhill, 2012:170).

The research strategy followed an experimental approach in which the researcher used hypotheses rather than research questions to anticipate whether or not a relationship existed between the variables under study. The design was cross-sectional to include data of all the 21 entities at one point in time. The current research was interested in the first 5 years of the business cycle after the guideline on executive remuneration had been revised in 2011. Thus, the secondary data collected were on the 2015 annual financial statement valid until March 2016 of all the 21 Schedule 2 South African SOEs.

\section{Research method Population and sample}

The target population consisted of 222 executives from 21 SOEs under Schedule 2 organisations as defined in the PFMA. The South African SOEs that currently fall under the Schedule 2 SOEs are Alexkor, ACCSA, ARMCO, ATNSA, Broadband 
Infraco, CEF, IDC, IDT, Land Bank, PBMR, SAA, SA Express, SAFCOL, DBSA, Denel, Eskom, Transnet, SAFCOL, SABC, SAPO and TELKOM. The study used purposive sampling (also known as judgemental sampling) (Saunders et. al., 2012). In purposive sampling, the sample is taken for a particular purpose (Leedy \& Ormrod, 2013: 215). Purposive sampling is a non-probability sampling technique that provides a range of alternatives to select samples, the majority of which include an element of subjective judgement (Saunders et al., 2012). In purposive sampling, the researcher selects cases that will best enable him or her to meet research objectives. Purposive sampling is often applied when working with small samples, such as in case study research and when the researcher wishes to select particular informative cases (Neuman, 2005). Thus, a purposive sample was relevant in the context of this study as the objective was to investigate the relationship between the determinants of remuneration of executives, which is a small sample compared with the general employees within an organisation. The purposive sampling consisted of executives who fall under the top management team as arranged according to Paterson grading E - lower to F - upper (including CEOs, directors and senior managers). On average, each enterprise consisted of 10 executives. The unit of analysis consisted of executives, type of industry, organisation size, job function and level of education.

\section{Research procedure}

The research was conducted on secondary data analysis. The access of such data was through the Internet. The researcher obtained measures of the focal variables from company annual statements available on the companies' websites. The verification of the collected data was through HR personnel at some of the SOEs where information was not clear.

The empirical data collected consisted of a salary corpus that contained information about the salary information of the executives, the size of the organisation (measured by the number of employees), job function (measured by the various categories of executive positions) and type of industry (e.g. transportation/freight logistics, defence, energy, forestry, telecommunications, development funding and aviation/ aerospace). The researcher also consulted data available from Bloomberg and MacGregor. These websites were helpful to some extent. However, some of their data were not current in terms of executives that the company websites contain.

The data collected on the variables under study were converted into different measurement scales. A nominal scale was applied to categorise data into seven types of industries. These groups were assigned code numbers that ranged from 1 to 7 , but not in order of importance. These code numbers served as convenient category labels with no intrinsic value, other than to assign to one of the seven nonoverlapping and mutually exclusive categories. An ordinal scale was applied to convert data on educational qualification. The reason to use the level of education as an ordinal scale is that an ordinal scale not only categorises the variables in such a way that denotes differences amongst the various categories, but it also rank orders them in some meaningful way. For example, the ordinal scale ranked qualifications from the lowest to the highest, assigning number 1 to a diploma, number 2 to a degree, number 3 to an honours degree, number 4 to a master's degree and number 5 to a doctoral degree. The same treatment was applied for the categorisation of different job functions. For example, the scale categorised executives (including CEOs, directors and senior managers) according to Paterson grading E - lower to $\mathrm{F}$ - upper. The lowest grade was assigned number 1 and the highest grade was assigned number 5 . The research design was cross-sectional. These are the data collected on the first 5 years of the business cycle after the guideline on executive remuneration had been revised in 2011. The data were based on the review of the 2015 annual financial statement.

\section{Data processing}

The SPSS, Version 20.0 (a statistical programme for social sciences) for statistical analysis was used to process the corpus of salary data of all the organisations under study. Descriptive statistics (such as mean, standard deviation and range), frequency distribution (percentages), and correlation coefficients calculated and summarised variables numerically (Saunders et al., 2007).

\section{Statistical analysis}

The study applied the categorical regression analysis. Categorical data refer to data whose values cannot be measured numerically, but classified into sets (categories) according to the characteristics that identify or describe the variable or placed rank order (Berman Brown \& Sanders, 2008). Categorical data known as descriptive or nominal data make it possible to count the number of occurrences in each category of a variable (Saunders et al., 2012).

The study involved a multi-variable problem - that is, more than one IV is studied. A categorical multiple regression analysis was applied because according to Albright et al. (2006), it represents an improvement over simple regression analysis and allows any number of explanatory variables in the analysis. For this particular study, a categorical regression analysis specified the extent of the relationship between the variables that fell into different categories, with a combination of interval, ordinal and nominal data. Thus, the results were analysed using non-parametric testing.

The current study used proportional-reduction-in-error interpretation (Lambda) as one measure of establishing the relationship between variables. Lambda is an asymmetrical measure of association suitable for use with nominal variables (Frankfort-Nachmias \& Leon-Guerrero, 2006). Lambda is relevant because the study measured the relationship between more than one variable at the nominal level. 
Thus, for the relationship between nominal variables, which include industry and size of the organisation, job function and type of industry, and job function and size of the organisation, the researcher used the Lambda test. For the relationship between the nominal variable (job function) and the ordinal variable (the level of qualification), the researcher used Eta and chi-squared $(\chi 2)$ tests. The chi-squared test was used to determine how closely observed frequencies or probabilities match. A chi-square is relevant as it can compute nominal, ordinal, interval or ratio data (Leedy \& Ormrod, 2013).

The researcher set the significance level criteria at 95\% confidence interval level $p \leq 0.05$ in order to counter the probability of a type 1 error. Hypotheses are accepted or rejected based on statistical likelihood. A type 1 error occurs when a true null hypothesis is mistakenly rejected. A type 2 error occurs when a false null hypothesis is mistakenly accepted. The researcher indicates how sure he wants to be that he is not committing a type 1 error in the selection of an alpha level (Johnson \& Reynolds, 2011).

However, statistical significance provides the reader with only a partial explanation of the importance of the results (Kirk, 1996). Fisher (1925) proposed that when reporting research findings, researchers should also present measures of the strength of association or correlation ratios. That is, the statistical significance alone may not be enough without including the effect size as a measure. An effect size calculated from data is a descriptive statistic that conveys the estimated magnitude of a relationship between variables in terms of standard deviation units, thereby putting the magnitude of the difference into context (Cohen, 1992).

Similarly, Sullivan (2012) contends that the level of significance by itself does not predict effect size. Unlike significance tests, the effect size is independent of sample size. Sometimes a statistically significant result only means that the study had a large sample size. For this reason, $p$ values become confounded because of their dependence on sample size. Effect size differs from significance tests because it focuses on the meaning of the results and enables a comparison between variables for the researcher to judge the practical significance of quantitative research results. Statistical significance, however, depends upon both sample size and effect size.

For the reader to appreciate the magnitude or importance of a study's findings, it is almost necessary to include some measure of effect size in the Results section (APA, 2009, p. 34). Effect sizes indicate categories, such as small, medium and large. The current research measures the effect size using different scores ranging from no correlation (0.00) to weak correlation $(+0.01-0.09)$, moderate correlation $(+0.10-0.29)$ to evidence of strong correlation $(+0.30-0.99)$ and perfect correlation, strongest possible $(+1.00)$. The measure is based on SPSS correlation coefficients as cited by Britton (2014)

\section{Ethical consideration}

Ethical clearance was issued by the Department of Industrial and Organisational Psychology, College of Economic and Management Sciences, University of South Africa (ERC reference no. 2018_CEMS/IOP_001). Ethical clearance was received on 14 March 2018.

\section{Results \\ Descriptive statistics}

The organisation size composition of the sample shows that the majority of executives in the sample were in organisation size (1001-10 000 employees) at $40.1 \%$ followed by organisation size (501-1000 employees) at 18\%, organisation size (50-500 employees) at $17.1 \%$ and organisation size (10 001-50 000 employees) at $15.8 \%$. The least represented is organisation size (50 001-100 000 employees) at 9\%. Table 1 also indicates that, on average, organisation size (50 001-100 000 employees) is leading in terms of the distribution of executive remuneration at (2606.55), followed by organisation size (10 001-50 000 employees) at (2197.66) and organisation size (501-1000 employees) at (1651.37). Whilst organisation size (50-500 employees) at (1542.03) and organisation size (1001-10 000 employees) at (1376.15) were the lowest in terms of the distribution of executive compensation.

The job function composition of the sample shows that administration is in the majority constituting (25.8\%) followed by operations at $(21.3 \%)$. The least represented job functions are IT at (3.6\%) followed by a dual role of strategy and finance at $(2.7 \%)$, and strategy and admin at (2.3\%). Table 2 also indicates that, on average, strategy and finance at (2192.67) is leading in terms of the distribution of remuneration, followed by strategy at (2049.31) and IT at (2053.88). Research and development (1085.00) was the lowest in terms of the distribution of executive compensation.

TABLE 1: Remuneration distribution of the sample by organisation size (number of employees).

\begin{tabular}{|c|c|c|c|c|c|c|}
\hline Company size & Number of employees & Percentage & Minimum & Maximum & Mean & Standard deviation \\
\hline $50-500$ & 38 & 17.1 & 529 & 3276 & 1542.03 & 567.946 \\
\hline 501-1000 & 40 & 18.0 & 739 & 3557 & 1651.37 & 527.648 \\
\hline $1001-10000$ & 89 & 40.1 & 121 & 3756 & 1376.15 & 755.887 \\
\hline $10001-50000$ & 35 & 15.8 & 652 & 3848 & 2197.66 & 796.085 \\
\hline $50001-100000$ & 20 & 9.0 & 407 & 3318 & 2606.55 & 805.253 \\
\hline Total & 222 & - & - & - & - & - \\
\hline
\end{tabular}


TABLE 2: Remuneration distribution of the sample by job function.

\begin{tabular}{|c|c|c|c|c|c|c|}
\hline Job function & Number of employees & Percentage & Mean & Standard deviation & Minimum & Maximum \\
\hline 1. Administration & 57 & 25.8 & 1823.40 & 993.941 & 121 & 3756 \\
\hline 2. Finance & 22 & 10.0 & 1719.55 & 883.660 & 146 & 3557 \\
\hline 3. Human resources & 27 & 12.2 & 1631.15 & 737.393 & 123 & 3309 \\
\hline 4. Information technology & 8 & 3.6 & 2053.88 & 809.060 & 1224 & 3488 \\
\hline 5. Legal and risk & 22 & 10.0 & 1261.41 & 614.684 & 123 & 2629 \\
\hline 6. Sales and marketing & 13 & 5.9 & 1799.00 & 728.474 & 1049 & 3060 \\
\hline 7. Operations & 47 & 21.3 & 1574.87 & 538.536 & 652 & 2666 \\
\hline 8. Research and development & 1 & 0.5 & 1085.00 & - & 1085 & 1085 \\
\hline 9. Strategy & 13 & 5.9 & 2049.31 & 753.217 & 1238 & 3848 \\
\hline 10. Strategy and admin & 5 & 2.3 & 1310.20 & 697.837 & 706 & 2399 \\
\hline 11. Strategy and finance & 6 & 2.7 & 2192.67 & 914.275 & 1338 & 3510 \\
\hline Total & 221 & - & - & - & - & - \\
\hline
\end{tabular}

TABLE 3: Remuneration distribution of the sample by type of industry.

\begin{tabular}{|c|c|c|c|c|c|c|}
\hline Industry & Number of employees & Percentage & Minimum & Maximum & Mean & Standard deviation \\
\hline 1. Aviation and aerospace & 36 & 16.2 & 697 & 3756 & 1806.89 & 651.390 \\
\hline 2. Defence & 14 & 6.3 & 706 & 3488 & 1471.79 & 778.675 \\
\hline 3. Development funding & 40 & 18.0 & 739 & 3557 & 1780.40 & 588.820 \\
\hline 4. Energy & 27 & 12.2 & 529 & 3107 & 1876.19 & 756.463 \\
\hline 5. Forestry & 12 & 5.4 & 533 & 2265 & 1195.42 & 437.403 \\
\hline 6. Telecommunications & 73 & 32.9 & 121 & 3848 & 1399.67 & 821.177 \\
\hline 7. Transportation/freight logistics & 20 & 9.0 & 407 & 3318 & 2606.55 & 805.253 \\
\hline Total & 222 & - & - & - & - & - \\
\hline
\end{tabular}

The industry composition of the sample shows that entities in telecommunications are in the majority constituting $32.9 \%$, followed by development funding at $(18.0 \%)$, aviation and aerospace at $(16.2 \%)$, and energy at $(12.2 \%)$. The least represented industry at $(6.3 \%)$ is defence. Table 3 also indicates that, on average, transportation/freight logistics (2606.55), energy (1876.19), aviation and aerospace (1806.89), and development funding (1780.40) were leading in terms of the distribution of executive compensation. Whilst defence (1471.79), telecommunications (1399.67) and forestry (1195.42) were the lowest in terms of the distribution of executive compensation.

The qualification composition of the sample shows that most executives possess a master's degree at $(53.6 \%)$, followed by those with a bachelor's degree at (20.6\%), an honours degree at $(15.3 \%)$ and a doctoral degree at (5.7\%). Executives with a diploma are fewest in number at (4.8\%). Table 4 also indicates that, on average, executives with a bachelor's degree (1782.33), a master's degree (1762.20) and an honours degree (1751.06) were leading in terms of the distribution of remuneration. Executives with a doctoral degree were the lowest (1563.75) whilst executives with a diploma were the least (1404.10) in terms of the distribution of executive remuneration in the sample.

\section{The relationship between the determinants of executive remuneration}

The results report on the correlation of the determinants of executive remuneration within the context of South African SOEs. In order to test the hypotheses, the product-moment correlation ( $r$ ) was utilised. As mentioned above, the significance value was set at a 95\% confidence interval level
TABLE 4: Remuneration distribution of the sample by level of education. Qualification Mean Number of Standard Minimum Maximum Percentage $\begin{array}{ll}\text { code } & \text { employees deviation }\end{array}$

\begin{tabular}{lcccccc}
\hline Diploma & 1404.10 & 10 & 559.845 & 681 & 2622 & $4.8 \%$ \\
$\begin{array}{l}\text { Bachelor's } \\
\text { degree }\end{array}$ & 1782.33 & 43 & 868.696 & 123 & 3756 & $20.6 \%$ \\
$\begin{array}{l}\text { Honours } \\
\text { degree }\end{array}$ & 1751.06 & 32 & 905.333 & 146 & 3848 & $15.3 \%$ \\
$\begin{array}{l}\text { Master's } \\
\text { degree }\end{array}$ & 1762.20 & 112 & 781.940 & 123 & 3557 & $56.3 \%$ \\
$\begin{array}{l}\text { Doctoral } \\
\text { degree }\end{array}$ & 1563.75 & 12 & 589.021 & 1085 & 2781 & $5.7 \%$ \\
\hline Total & - & 209 & - & - & - & - \\
\hline
\end{tabular}

$(p \leq 0.05)$ in order to counter the probability of a type 1 error. However, the correlation between the variables under study is supplemented by the effect of size to reveal the depth of the correlation.

For the current research, the strength of the correlation is measured using different categories of scores ranging from no correlation (0.00) to weak correlation (+0.01-0.09), moderate correlation $(+0.10-0.29)$ to evidence of strong correlation $(+0.30-0.99)$, and perfect correlation, strongest possible $(+1.00)$ (Britton, 2014).

Table 5 indicates the standard error (SE) of the different correlation between the variables. The SE error represents measures of spread. The higher the number, the more spread out the sample data to the mean. In the current study, 0.049 is the highest spread of the correlation between industry and organisation compared with the correlation between other variables as determinants of executive remuneration. The $t$-tests are hypothesis tests for the mean and use the $t$-distribution to determine statistical significance. A sample $t$-test determines whether the difference between the 
TABLE 5: Correlation coefficients indicating the relationships between the independent variables to executive remuneration.

\begin{tabular}{lccccccc}
\hline Variable & SE & $p$ & $t$ & Lambda & $\left(\chi^{2}\right)$ & $d f$ & Eta \\
\hline Correlated variables & & & & & & & \\
Symmetric value & 0.049 & $0.000^{*}$ & 7.227 & 0.433 & - & - & - \\
Industry & - & - & - & 0.369 & - & - & - \\
Organisation size & - & - & - & 0.504 & - & - & - \\
Symmetric value & 0.024 & $0.003^{*}$ & 3.004 & 0.074 & - & - & - \\
Job function & - & - & - & 0.116 & - & - & - \\
Industry & - & - & - & 0.027 & - & - & - \\
Symmetric value & 0.020 & $0.036^{*}$ & 2.102 & 0.044 & - & - & - \\
Job function & - & - & - & 0.055 & - & - & - \\
Organisation size & - & - & - & 0.030 & - & - & - \\
Value & - & $0.001^{*}$ & - & - & 72.004 & 40 & - \\
Job function & - & - & - & - & - & - & 0.125 \\
Level of education & - & - & - & - & - & - & 0.303 \\
\hline$N=222 ; *$
\end{tabular}

sample mean and the null hypothesis value is statistically significant. The chi-squared test of independence determines whether there is a statistically significant relationship between categorical variables. A chi-square represents the observed frequency for each combination of categorical variables. The test determines whether the entire set of differences exceeds a significance threshold. If the $\chi^{2}$ passes the limit, the results are statistically significant. A chi-square with a score of zero means the null hypothesis is accepted. Larger values, for example 0.72 in this study, represent a greater difference between the sample data and the null hypothesis, and thus the null hypothesis is rejected and the alternate hypothesis is accepted.

Just like any other hypothesis tests, the testing incorporates degrees of freedom. Degrees of freedom are the number of independent values that a statistical analysis can estimate. Many families of distributions, like $t$ and $\chi 2$, use degrees of freedom to specify which specific $t$ or $\chi^{2}$ distribution is appropriate for different sample sizes and different numbers of model parameters. For example, for a $\chi 2$ test, a $p$-value that is less than or equal to 0.05 significance level indicates there is sufficient evidence to conclude that a relationship exists between the categorical variables.

Eta squared is the proportion of variance associated with one or more main effects, errors or interactions in ANOVA. Etasquared ranges from 0 to 1 and indicates the proportion of overlap between the grouping variable (the IV) and the outcome variable. If the model has more than one IV, the researcher is advised to report the partial Eta-squared for each (Aaron, Kromrey, \& Ferron, 1998; Coe, 2002; Thalheimer \& Cook, 2002; Ward, 2002; Wilkinson \& APA, 1999). Partial Eta-squared indicates the percentage (\%) of variance in the $\mathrm{DV}$, for example, executive remuneration (DV), attributable to a particular (IVs) job function (13\%) and level of education $(30 \%)$.

Lambda is used to investigate the measure of association that is suitable for use with nominal variables. Lambda was used to investigate the two variables under study. Lambda is defined as an asymmetrical measure of association that is suitable for use with nominal variables (Frankfort-Nachmias \& Leon-Guerrero, 2006). It may range from 0.0 to 1.0. Lambda provides the researcher with an indication of the strength of the relationship between IV and DV.

\section{Type of industry and organisation size}

According to the measure of nominal variables between the size of the organisation and type of industry, a $p<0.000^{*}$ suggests that there is a statistically significant correlation between the two variables tested as determinants of executive remuneration. The significance level was at $p<0.05$, that is, at a $95 \%$ confidence interval level. The results were also significant at the stringent significance level $p<0.01$, that is, $99 \%$ confidence interval level. Similarly, the t-tests of 7.227, the standard deviation of 0.049 and $p=0.000 *$ suggest that there is a significant correlation between the size of the organisation and type of industry in South African SOEs. The symmetric Lambda value of 0.433 also suggests that there is evidence of a strong correlation between the type of industry and the organisation size. Overall, from this analysis, the hypothesis of the statistically significant relationship between the two variables is supported:

H(1): A statistically significant correlation exists between organisation size and the type of industry as a determinant of executive remuneration within the context of South African SOEs.

However, the results also suggest that the extent of the correlation between the type of industry and organisation size as determinants of executive remuneration is not the same within the context of South African SOEs. The organisation size Lambda value of 0.504 suggests that there the organisation size is a stronger determinant of executive remuneration when compared with the type of industry Lambda value of 0.369 with job function within the context of South African SOEs. From this analysis, the hypothesis on the extent of the relationship between the two variables is not supported:

$\mathbf{H}(2)$ : The extent of the correlation between organisation size and type of industry as a determinant of executive remuneration is not the same in the context of South African SOEs.

The results suggest that the type of industry is less strong as a determinant of executive remuneration when compared with organisation size within the context of South African SOEs.

\section{Type of industry and job function}

The measure of nominal variables between job function and type of industry, the result of the study at $p<0.003^{*}$, suggests that there is a significant correlation between the two variables as a determinant of executive remuneration. In addition, the t-tests 3.004, standard deviation 0.024 and $p<0.003^{*}$ suggest that there is a significant correlation between the type of industry and job function as a determinant 
of executive remuneration within the context of South African SOEs. The hypothesis on the statistical significant correlation between the two variables is supported:

$\mathbf{H ( 3 ) : ~ A ~ s t a t i s t i c a l l y ~ s i g n i f i c a n t ~ c o r r e l a t i o n ~ e x i s t s ~ b e t w e e n ~ t h e ~}$ type of industry and job function as a determinant of executive remuneration within the context of South African SOEs.

However, the extent of the correlation between the type of industry and job function as a determinant of executive remuneration is not the same within the context of South African SOEs. The symmetric Lambda value of 0.074 may, however, suggest that there is evidence of a weak correlation between the type of industry and job function in relation to executive remuneration within the context of South African SOEs. In particular, a comparison of job function Lambda value of 0.116 with industry Lambda value of 0.027 suggests that the type of industry is a weaker determinant of executive remuneration when compared with job function within the context of South African SOEs. The hypothesis on the extent of the correlation between the two variables is not supported:

$\mathbf{H}(4)$ : The extent of the correlation between job function and type of industry as a determinant of executive remuneration is not the same in the context of South African SOEs.

The results suggest that the type of industry is a weaker determinant of executive remuneration when compared with job function within the context of South African SOEs.

\section{Organisation size and job function}

The measure of nominal variables between organisation size and job function indicates a significant $p$ value of $0.036^{*}$. The result suggests that there is a significant correlation between the two variables as a determinant of executive remuneration within the context of South African SOEs. In addition, the t-tests of 2.102, standard deviation of 0.020 and $p<0.036^{*}$ suggest that there is a significant correlation between the organisation size and job function as a determinant of executive remuneration. However, the symmetric Lambda value of 0.044 may suggest that there is evidence of a weak correlation between organisation size and job function as a determinant of executive remuneration within the context of South African SOEs. Nonetheless, the hypothesis on the statistical significant correlation between the two variables is supported:

$\mathbf{H ( 5 ) : ~ A ~ s t a t i s t i c a l l y ~ s i g n i f i c a n t ~ r e l a t i o n s h i p ~ e x i s t s ~ b e t w e e n ~ t h e ~}$ organisation size and job function as a determinant of executive remuneration in the context of South African SOEs.

However, the extent of the correlation between the organisation size and job function is not the same within the context of South African SOEs. Further, a comparison of the organisation size Lambda value of 0.030 to job function Lambda value of 0.055 suggests that even though there is a weak correlation between the two variables towards remuneration, there is however a better correlation of the job function (0.055) to executive remuneration compared with the organisation size Lambda of value 0.030 to executive remuneration. The hypothesis on the extent of the correlation between the two variables is not supported:

$\mathbf{H}(6)$ : The extent of the correlation between the organisation size and job function as a determinant of executive remuneration is not the same in the context of South African SOEs.

The results suggest that the organisation size is a weaker determinant of executive remuneration when compared with job function within the context of South African SOEs. This may suggest that one cannot rely entirely on the size of the organisation according to which a job function could be compensated.

\section{Level of education and job function}

The data were analysed using Pearson 2 test. The correlation between the level of qualifications (ordinal) and job function (nominal) was measured. The number of valid cases of executives sampled was 208, and these were evaluated to determine as to whether there was a significant correlation between the two variables as a determinant of executive remuneration. The $p$ value, also called significant value (Asymp. Sig.), has a predictive value that is more important as an indicator of the relationship. The lower the significant value, the less likely it is that the two variables are independent (unrelated or not correlated). For this current study, the significant level selected is $p$ value lower than 0.05 , that is, at $95 \%$ confidence level. In this case, the measure of the two variables between job function (nominal) and level of qualifications (ordinal) indicates a significant $p<0.001 *$, which suggests that the two variables are, indeed, related as a determinant of executive remuneration within the context of South African SOEs.

Also, a significant correlation exists between the two variables, as the chi-square $\chi^{2}(1)=72.0$ is high, and the $p<0.001 *$ is lower than the $p$-value 0.05 . Based on the results, the hypothesis of the statistically significant correlation between the two variables is supported:

$\mathbf{H}(7)$ : A statistically significant correlation exists between the level of qualifications and job function as a determinant of executive remuneration in the context of South African SOEs.

However, the extent of the correlation between the level of qualifications and job function is not the same within the context of South African SOEs. The Eta-squared was used to interpret the extent of the effect size as a determinant of executive remuneration. With the Eta at 0.125 for job function and 0.303 for the level of qualifications, the result seems to suggest that the level of qualifications is a better determinant of executive remuneration when compared to the job function. In other words, the job function (IV) explained $13 \%$ of the variance in the DV (executive remuneration) compared with the level of education (IV) that explained $30 \%$ of the variance in the DV (executive remuneration). The hypothesis on the extent of the correlation between the two variables is not supported:

$\mathbf{H ( 8 ) : ~ T h e ~ e x t e n t ~ o f ~ t h e ~ c o r r e l a t i o n ~ b e t w e e n ~ t h e ~ l e v e l ~ o f ~ e d u c a t i o n ~}$ and job function as a determinant of executive remuneration is not the same in the context of South African SOEs. 
Thus, the statistical correlation between the level of education and job function seems to suggest that the level of education is a better indicator and determinant of executive remuneration when compared with the job function within the context of South African SOEs.

\section{Discussion}

A review of theory and the guidelines from the South African SOEs preceded the study on the determinants of executive remuneration. An empirical test was conducted on data 5 years after the revised guidelines was published in 2011. Although the guidelines focussed on the size of the organisation amongst other factors, such as revenue, asset base, and external and internal factors, the empirical study in this research focused on some of the popularly used determinants of executive remuneration in theory and practice, and not on the guideline per se. The difference with the current study is that the variables that, in some research, are investigated individually in relation to executive remuneration are correlated in this study to reveal their extent to which they determine executive remuneration.

The statistical correlation between the type of industry and organisation size suggests that there is a statistically significant correlation between the two variables tested as a determinant of executive remuneration. However, the extent of the relationship between the two variables seems to suggest that it is possible to estimate an executives' package by relying more on the organisation size than the type of industry. The results seem consistent with previous studies and literature findings, which contend that remuneration tends to correlate with organisation size (Bouwman, 2013; Edmans \& Gabaix, 2015; Nourayi \& Daroca, 2008; Sigler, 2011). Similarly, larger organisations require a higher level of responsibility and have more complex tasks, which may warrant higher pay (Frydman \& Saks, 2010; Oberholzer \& Theunissen, 2012; Papenfuß \& Schmidt, 2015). The research results seem consistent with the tenet of the structural theory that argues that executive compensation is a direct function of the number of organisational levels an executive occupies. The results imply that executive remuneration should rise along with an increase in the size of a typical SOE.

The statistical correlation between the type of industry and job function suggests that there is a significant correlation between the two variables as a determinant of executive remuneration within the context of South African SOEs. However, the extent of the relationship between the two variables seems to suggest that there is evidence of a weak correlation between organisation size and job function as a determinant of executive remuneration within the context of South African SOEs. A comparison of job function Lambda value of 0.116 with industry Lambda value of 0.027 suggests that the type of industry may be a weaker determinant of executive remuneration when compared with job function within the context of South African SOEs. However, as the correlation between the two variables is weak, this may imply that it would be difficult to see the practical effect of one variable against another as a determinant of executive remuneration within the context of South African SOEs. The research results of the current study support those of Larker and Tayan (2011), Marcinkowska (2014), Papenfuß and Schmidt (2015) who contend that the type of industry poses problems as a determinant of executive remuneration. Using peer group or similar job function in the industry in which a job function could benchmark against a competitive disadvantage could arise resulting in stable median not achieved (Larker \& Tayan, 2011, p. 247-248), and paying well below or well above the typical market rate for jobs. Consistent with the contingency theory, the current research results imply that using peer group would have a ratcheting effect. When multiple SOEs try to meet or exceed the median, the median increases (Larker \& Tayan, 2011; Marcinkowska, 2014; Papenfuß \& Schmidt, 2015). The implication for SOEs is that industry is, therefore, less reliable as a determinant of executive remuneration compared with job function within the context of South African SOEs.

The statistical correlation between organisation size and job function seems to suggest that there is a significant correlation between the two variables as a determinant of executive remuneration within the context of South African SOEs. However, the symmetric Lambda value of 0.044 may suggest that there is evidence of a weak correlation between organisation size and job function as a determinant of executive remuneration within the context of South African SOEs. A comparison of organisation size Lambda value of 0.030 with job function Lambda value of 0.055 suggests that the organisation size may be a weaker determinant of executive remuneration when compared with job function within the context of South African SOEs. However, as the correlation between the two variables is weak, this may imply that the practical effect of one variable against another as a determinant of executive remuneration may not indicate much of a difference within the context of South African SOEs. The finding contradicts that of previous studies (Bouwman, 2013; Edmans \& Gabaix, 2015; Hijazi \& Bhatti, 2007; Nourayi \& Daroca, 2008; Sigler, 2011), which contend that remuneration tends to correlate highly with organisation size. The research results seem consistent with the tenet of the structural theory, which argues that executive compensation is a direct function of the number of organisational levels an executive occupies or the rank and order of the position within the organisation. The results may imply that executive remuneration should rise along with the complexity of the job function. However, as already indicated in this study that there is evidence of a weak correlation between the two variables, this may imply that it would be difficult to see the extent and practical effect of one variable against another as a determinant of executive remuneration within the context of South African SOEs.

The statistical correlation between the level of education and job function suggests that there is a significant correlation between the two variables as determinants of executive 
remuneration within the context of South African SOEs. However, the extent of the relationship seems to suggest that the former is a better determinant of executive remuneration compared to the latter within the context of South African SOEs. In other words, the results seem to mean an executive with higher qualifications stood to earn more than another executive with lesser qualifications on a similar job function at another entity across the different SOEs. The result seems consistent with previous studies that contend that more education positively correlates to annual income and leads to higher remuneration and personal rewards (Greve et al., 2010) and that organisations have to pay highly competitive wages in order to hire well-educated employees (Denenga, 2012; Myers et al., 2004). The research results also seem consistent with the major tenet of human capital theory that postulates that the acquisition of education increases knowledge and skills, which in turn leads to higher remuneration and personal rewards (Becker, 1964; Greve et al., 2010; Ng \& Feldman, 2010; Strober, 1990).

\section{Practical implications}

What can we learn from this research? There are several important takeaways from this research. Firstly, HR practitioners and remuneration specialists need to take into cognisance that the type of industry seems not to be a good determinant of executive remuneration within the context of South African SOEs. The lack of clearly defined industries in both the private and the public sector that are comparable to the SOEs seems to compound the problem.

Secondly, HR practitioners and remuneration specialists need to realise that whilst there is a strong correlation of organisation size to industry, this correlation is not as strong as reported by some previous research (Bouwman, 2013; Edmans \& Gabaix, 2015; Nourayi \& Daroca, 2008; Sigler, 2011) within the context of SOEs. The result seems to suggest that the HR division may need to identify criteria to define the size of the organisation as well as the industry for the SOE sector. As suggested by Seegers (PwC, 2010) cited in Oberholzer and Theunissen (2012), believes that new executive reward models tailored to specific businesses should be relevant and simple in terms of design and number of elements required. According to Seegers, existing executive pay models have failed and what is needed is a businessspecific, multi-element model to benchmark executive remuneration and a simple two-dimensional model will therefore not suffice. Thus, identifying a single driver and its correlation to executive remuneration may restrict creativity and limit understanding and insight.

In this study, the size of the organisation correlates to executive remuneration but less as a determinant compared with the job function may highlight how establishing the size of an SOE differs when compared to how it is down in the private sector. With SOEs distinguished into four different categories according to the remuneration guidelines of 2007 revised in 2011, however, the issue with correct levels of the distribution of executive remuneration is still not resolved. Another concern raised about benchmarking remuneration against JSE-listed companies remains (Kgosana, 2012). The SOEs (sector) do not seem to have an industry comparable to all entities as they differ in terms of the nature of their business and their developmental mandate.

Lastly, although the level of education has appeared as highly significant when correlated with job function, advisors and consultants should take precautions in the application. Advising SOEs to adopt policies that would emphasise the level of education over the job function may underplay other elements, such as experience that is an element not tested in the current study.

This study also demonstrates the advantages of secondary data analysis. It offers an opportunity to revert to documented information. The investigator is in a better position which may not necessarily be affected by the evolution of events and developments that may interfere or affect the collection of data, such as in the collection of primary data. Documented information, especially on remuneration, can provide as much knowledge or even better insight as primary data collected using respondents. Thus, the use of secondary data analysis can have a meaningful contribution to the application of executive remuneration in practice.

Secondary data also mitigate the challenges of collecting data on remuneration from respondents who may not necessarily know how the different levels are arrived at because such information could only be available to a few HR personnel.

The article intends to stimulate debate amongst practitioners, some of whom may focus on one determinant of the executive remuneration when in practice it has shown that there may be more determinants at play when setting executive remuneration. Some of the studies identified within the literature review continue to research executive remuneration, but there seems to be no 'one-size-fits-all' approach. The current study attempted to engage at the fundamental level by investigating the relationship between the popularly used determinants of executive remuneration. This study intended to highlight the fact that measuring executive remuneration should not be a complicated process.

\section{Limitations and recommendations}

There are a plethora of elements in the determination of executive remuneration. However, this study investigated a few popularly used determinants in practice. Although South African SOEs consist of 131 SOEs (National Government Directory: SOEs, 2020), only 21 Schedule 2 SOEs were studied. The data collected were for a period of 5 years after the guidelines on executive remuneration had been revised and published. A follow-up study would be interesting to investigate if there has been any change in the relationship between the determinants after the first 5 years, that is, 10 years later, as at the end of 2020. 


\section{Conclusion}

The overall results seem to suggest that job function is a better determinant of executive remuneration when compared to the organisation size. However, the job function was even better when compared to the type of industry, but not when compared to the level of education within the context of South African SOEs.

The current study highlights some of the aspects necessary to understand the theory and operations that underpin executive remuneration. The study also intended to create awareness of the need to probe further the extent of the significance of statistics and implications in practice. The study also stimulates further need to investigate the combination of more than two elements of executive remuneration. For example, a new study could investigate how job function relates to the size of the organisation and the type of industry as a determinant of an executive's package. Such a study could unveil further dynamics that characterise the determination of executive. Hopefully, the multiple approaches would shrink the level of anxiety and provide more insight into the debatable topic of executive remuneration. The one-size-fits-all approach in executive remuneration has been highlighted in theory, as well as in this study.

\section{Acknowledgements}

The author would like to acknowledge support from the Human Resources Representatives from the different SOEs who confirmed data from the website and also offered more information for clarification.

\section{Competing interests}

The author has declared that no competing interest exists.

\section{Author's contributions}

The author is solely responsible for the manuscript.

\section{Funding information}

This research received no specific grant from any funding agency in the public, commercial or not-for-profit sectors.

\section{Data availability statement}

Data sharing is not applicable to this article as no new data were created or analysed in this study.

\section{Disclaimer}

The views and opinions expressed in this article are those of the author and do not necessarily reflect the official policy or position of any affiliated agency of the author.

\section{References}

Aaron, B., Kromrey, J.D., \& Ferron, J.M. (1998, November). Equating r-based and d-based effect-size indices: Problems with a commonly recommended formula. Paper presented at the annual meeting of the Florida Educational Research Association, Orlando, FL. (ERIC Document Reproduction Service No. ED433353).
Agarwal, N.C. (1981). Determinants of executive compensation. Industrial Relations, 20(1), 36-45. https://doi.org/10.1111/j.1468-232X.1981.tb00180.x

Albright, S.C., Winston, W.L., Zappe, C.J., \& Broadie, M.N. (2009). Data analysis \& decision making with Microsoft Excel. Australia: Thomson South-Western.

Apanpa, B., \& Farinmade, B. (2017). Compensation philosophy: How do you intend to reward your employees? September. KPMG. Retrieved from https://home.kpmg/ content $/ \mathrm{dam} / \mathrm{kpmg} / \mathrm{ng} / \mathrm{pdf} / \mathrm{tax} / \mathrm{ng}$-compensation-philosophy.pdf

Armstrong, M., \& Brown, D. (2001). New dimensions in pay management. London: CIPD.

Becker, G. (1964). Human capital: A theoretical and empirical analysis with specia reference to education. New York, NY: Columbia University Press.

Berman Brown, R., \& Saunders, M. (2008) Dealing with statistics: What you need to know. Maidenhead: McGraw-Hill Open University Press.

Bernier, L. (2014). Public enterprises as policy instruments: The importance of public entrepreneurship, Journal of Economic Policy Reform, 17(3), 253-266. https://doi. org/10.1080/17487870.2014.909312

Bernier, L. (2015). Public Enterprises Today: Missions, Performance and Governance. Brussels, Belgium: PIE-Peter Lang SA.

Bognanno, M. (2010). Executive compensation: A brief review (No. 1002). Department of Economics, Temple University. Retrieved from http://ideas.repec.org/p/tem/ wpaper/1002.html

Boivie, S., Bednar, M.K., \& Barker, S.B. (2012). Social comparison and reciprocity in director compensation. Journal of Management, 41(6), 1578-1603. https://doi. org/10.1177/0149206312460680

Bouwman, C. (2013). The geography of executive compensation. Unpublished Working paper. Cleveland, $\mathrm{OH}$ : Case Western University.

Britton, D. (2014). SPSS eTutor. A brief guide book. Creative Commons AttributionNonCommercial-ShareAlike 3.0 Unported License. Retrieved from http:// commons.esc.edu/spss/examining-relationships-among-variables/measuresofassociation

Bullock, J.B., Stritch, J.M., \& Rainey, H.G. (2015). International comparison of public and private employees' work motives, attitudes, and perceived rewards. Public Administration Review, 75(3), 479-489. https://doi.org/10.1111/puar.12356

Bussin, M. (2018). Chief executive officer compensation sensitivity in the South African mining industry. Acta Commercii, 18(1), 1-13. https://doi.org/10.4102/ ac.v18i1.573

Carrasco-Hernandez, A., \& Sánchez-Marín, G. (2007). The determinants of employee compensation in family firms: Empirical evidence. Family Business Review, 20(3), 215-228. https://doi.org/10.1111/j.1741-6248.2007.00096.x

Clifford, S. (2017). How companies actually decide what to pay CEOs. The Atlantic Business. June 14. Retrieved from https://www.theatlantic.com/business/ archive/2017/06/how-companies-decide-ceo-pay/530127/

Coe, R. (2002). It's the effect size, stupid: What effect size is and why it is important Paper presented at the Annual Conference of British Education Research Association, University of Essex.

Cohen, J., (1992). Quantitative methods in psychology: A power primer. Psychologica Bulletin, 112(4), 155-159. https://doi.org/10.1037/0033-2909.112.1.155

Conyon, M., \& He, L. (2011). Executive compensation and corporate governance in China. Journal of Corporate Finance, 17(4), 1158-1175. https://doi.org/10.1016/j. jcorpfin.2011.04.006

Datta Gupta, N., Poulsen, A., \& Villeval, M.C. (2013). Gender matching and competitiveness: Experimental evidence. Economic Inquiry, 51(1), 816-835. https://doi.org/10.1111/j.1465-7295.2011.00378.x

Datta, S., \& Iskandar-Datta, M. (2014). Upper-echelon executive human capital and compensation: Generalist vs specialist skills. Strategic Management Journal, 35(12), 1853-1866. https://doi.org/10.1002/smj.2267

Del Bo, C., \& Florio, M. (2012). Public enterprises, planning and policy adoption: Three welfare propositions. Journal of Economic Policy Reform, 15(4), 263-279. https:// doi.org/10.1080/17487870.2012.722846

Denenga, L. (2012). Female wages and occupational advance under black economic empowerment in South Africa. Colgate Academic Review, 9, Article 9.

Deysel, B., \& Kruger, J. (2015). The relationship between South African CEO compensation and company performance in the banking industry. Southern African Business Review, 19(1), 137-169. https://doi.org/10.25159/19988125/5837

DPE. (2007). State-owned enterprises remuneration guidelines. Part A: Chairpersons \& Non-Executive Directors. Part B: Executive Directors. Retrieved from https://www. gov.za/sites/default/files/gcis_document/201409/seo-remuneration0.pdf

Ebrahimi, L, \& Horak, A. (2018). Is executive benchmarking as we know it dead? Executive directors: Practices and remuneration trends report. PwC. Retrieved from www.pwc.co.za/executive-directors-report

Edmans, A., \& Gabaix, X. (2016). Executive compensation: A modern primer. Journal of Economic literature, 54(4), 1232-1287. https://doi.org/10.1257/jel.20161153

Farid, M., Conte, V., \& Lazarus, H. (2011). Toward a general model for executive compensation. Journal of Management Development, 30(1), 61-74. https://doi. org/10.1108/02621711111098370

Farmer, M., Brown, D., Reilly, P., \& Bevan, S. (2013). Executive remuneration in the United Kingdom: Will the coalition government's latest reforms secure improvement and what else is required? Compensation \& Benefits Review, 45(1), 26-33. https://doi.org/10.1177/0886368713485037 
Fernandes, N, Ferreira, M.A., Matos, P., \& Murphy. K.J. (2013). Are U.S. CEOs paid more? New international evidence, Review of Financial Studies, 26(2), 323-367. https://doi.org/10.1093/rfs/hhs122

Fin24. (2010). Eskom executive pay up 25\%. Fin24.com. Retrieved from https://www. news24.com/fin24/Companies/Eskom-executive-pay-up-25-20100702

Fisher, R.A. (1925). Statistical methods for research workers. London: Oliver \& Boyd.

Fleming, A.S., \& Schaupp, L.C. (2011). Factor analysis of executive compensation determinants: Survey evidence from executives and non-executive Investors, determinants: Survey evidence from
Corporate Governance, 12(1), 16-41.

Frankfort-Nachmias, C., \& Leon-Guerrero, A. (2006). Social statistics for a diverse society. Thousand Oaks, CA: Pine Forge Press.

Frydman, C., \& Saks, R.E. (2010). Executive compensation: A new view from a long term perspective, 1936-2005. Review of Financial Studies, 23(5), 2099-2138. https://doi.org/10.1093/rfs/hhp120

Gabaix, X., \& Landier, A. (2008). Why has CEO pay increased so much? The Quarterly Journal of Economics, 123(1), 49-100. https://doi.org/10.1162/ qjec.2008.123.1.49

Geletkanycz, M.A., Boyd, B.K., \& Finkelstein, S. (2001). The strategic value of CEO external directorate networks: Implications for CEO compensation. Strategic Management Journal, 22(9), 889-898. https://doi.org/10.1002/smj.172

Ghose, A. (2011). Total rewards special: Decoding executive compensation Compensation Benefits. (March 15). AonHewitt. Retrieved from http://www.
peoplematters.in/article/2011/03/15/compensation-benefits/total-rewardspeoplematters.in/article/2011/03/15/comp
special-decoding-executivecompensation/882

Gomez-Mejia, L., Berrone, P \& Franco-Santos, M. (2010). Compensation and organizational performance: Theory, research, and practice. New York, NY: ME Sharpe.

Green, R. (2018). Candid remuneration reporting and clear disclosure. In Executive directors: Practices and remuneration trends report (10th edn., July 2018). PricewaterhouseCoopers.

Greve, A., Benassi, M., \& Sti, A.D. (2010). Exploring the contributions of human and social capital to productivity. International Review of Sociology-Revue Internationale de Sociologie, 20(1), 35-58.

Hall, B.J., \& Murphy, K.J. (2003). The trouble with stock options. Journal of Economic Perspectives, 17(3), 49-70.

Hijazi, S.T., \& Bhatti, K.K. (2007). Determinants of executive compensation and its impact on organizational performance. Compensation \& Benefits Review, 39(2), imp-68.

Howard, A. (1986). College experiences and managerial performance. Journal of Applied Psychology, 71(3), 530-552. https://doi.org/10.1037/0021-9010.71.3.530

IoDSA. (2016). King IV provides critical guidance to help companies solve remuneration issues. Institute of directors Southern Africa, November 21. Retrieved from https://www.iodsa.co.za/news/318424/King-IV-provides-critical-guidance-tohelp-companies-solve-remuneration-issues.htm

IoDSA. (2018). Remuneration policy. Southern Africa: Institute of Directors. Retrieved from https://cdn.ymaws.com/www.iodsa.co.za/resource/collection/ F85FOCDA-6820-4BBA-A467-ED6EE14B0EE5/IODSA\%20Remuneration\%20 Policy\%202018.pdf

Jensen, M., Murphy, K., \& Wruck, E. (2004). Remuneration: Where we've been, how we got to here, what are the problems, and how to fix them. ECGI working paper series in Finance working paper series, no. 44. Harvard University.

Johnson, J.B., \& Reynolds, H.T. (2011). Political science research methods. London: SAGE.

Kgosana, C. (2012a). Gigaba plans to curb executive pay. Sowetan. March, 14 Johannesburg, South Africa.

Kgosana, C. (2012b). State challenged on directors' pay freeze. Sowetan. April, 25.

Kirk, R.E. (1996). Practical significance: A concept whose time has come. Educational and Psychological Measurement, 56(5), 746-759. https://doi. org/10.1177/0013164496056005002

Kirsten, E., \& Du Toit, E. (2018). The relationship between remuneration and financial performance for companies listed on the Johannesburg Stock Exchange. South African Journal of Economic and Management Sciences, 21(1), 1-10. https://doi. org/10.4102/sajems.v21i1.2004

Kleynhans, M. (2018). Corporate failures: Their impact on executive remuneration In Executive directors: Practices and remuneration trends report (10th edn., July 2018). PricewaterhouseCoopers.

KPMG Forensic Report. (2010). February 10, 2011. Retrieved from www.pmg.org.za/ report/20100831-south-african-airways-kpmg-report-briefing

Larker, D., \& Tayan, B. (2011). Corporate governance matters. A closer look at organizational choices and their consequences. Upper Saddle River, NJ: Pearson Education.

Leedy, P.D., \& Ormrod, J.E. (2013). Practical research: Planning and design (10th edn.). Boston, MA: Pearson.

Magnan, M., \& Martin, D. (2018). Executive compensation and employee

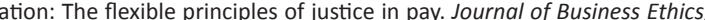
160(1), 1-17. https://doi.org/10.1007/s10551-018-3786-5

Maloa, F., \& Bussin, M. (2016). Determinants of executive compensation in South African state-owned enterprises. South African Journal of Labour Relations, 40(1) 8-24. https://doi.org/10.25159/2520-3223/5857

Marcinkowska, M. (2014). Remuneration of bank managers-problems and potential solutions. Argumenta Oeconomica, 32(1), 41-74.

Martocchio, J.J. (2011). Strategic compensation. Upper Saddle River, NJ: Prentice Hall.
Milkovich, G., \& Newman, J.M. (2004). Compensation (8th edn.). New York, NY: Mc Graw-Hill.

Milkovich, G.T., Newman, J.M., \& Gerhart, B. (2014). Compensation (11th edn.). International Edition. New York, NY: McGraw-Hill/Irwin.

Millward, R. (2011). Public enterprise in the modern western world: An historical analysis. Annals of Public and Cooperative Economics, 82(4), 375-398. https:// doi.org/10.1111/j.1467-8292.2011.00447.x

Myers, M.B., Griffith, D.A, \& Daugherty, P.J. (2004). Maximizing the human capital equation in logistics: Education, experience, and skills. Journal of Business and Logistics, 25(1), 211-232. https://doi.org/10.1002/j.2158-1592.2004. tb00175.x

National-Government-Directory: State-Owned-Enterprises-SOEs. (2020). Retrieved from https://www.gov.za/about-government/contact-directory/ sub-category/national-government-directory\%3A-state-ownedenterprises$\% 28$ soes $\% 29 /$ pdf

National Treasury (2010). The framework for strategic plans and annual performance plan. Retrieved from www.treasury.gov.za

Neill, J.T. (2008). Why use effect sizes instead of significance testing in program evaluation? Retrieved from http://www.wilderdom.com/research/effectsizes.html.

Neuman, W.L. (2005) Social research methods (6th edn). London: Pearson.

Nourayi, M., \& Daroca, F. (2008), CEO compensation, firm performance, and operational characteristics. Managerial Finance, 34(8), 562. https://doi.org/ 10.1108/03074350810874082

Novak, J., \& Bilinski, P. (2018). Social stigma and executive compensation. Journal of Banking \& Finance, 96, 169-184. https://doi.org/10.1016/j.jbankfin.2018.09.003

Nulla, Y.M. (2013). A combined study of Canada's top CEO compensation sectors Energy, metal and mining - An empirical study. Strategic Management Quarterly, $1(1), 11-21$.

Oberholzer, M., \& Theunissen, M. (2012). Benchmarking of Johannesburg Stock Exchange CEO compensation. International Business \& Economics Research Journal (IBER), 11(9), 1061-1076. https://doi.org/10.19030/iber.v11i9.7189

OECD. (2005). OECD guidelines on corporate governance of state-owned enterprises. OECD. Publishing: Paris, France.

Pandher, G., \& Currie, R. (2013). CEO compensation: A resource advantage and stakeholder-bargaining perspective. Strategic Management Journal, 34(1), 22-41. https://doi.org/10.1002/smj.1995

Papenfuß, U., \& Schmidt, C. (2015). Determinants of manager pay in German stateowned enterprises and International public policy implications: 3-year study for sectors, performance and gender (no. 137). Working Paper, Universität Leipzig, Wirtschaftswissenschaftliche Fakultät.

Peng, M.W., Sun, S.L., \& Markóczy, L. (2014). Human capital and CEO compensation during institutional transitions. Journal of Management Studies, 52(1), 117-147. https://doi.org/10.1111/joms.12106

Perkins, S.J., \& White, G. (2011). Reward management: Alternatives, consequences and contexts (2nd edn.). London: Chartered Institute of Personnel and Development.

Public Finance Management Act of 1999. Retrieved from http://www.treasury.gov.za/

Pugh, D.S. (1973). The measurement of organisation structures: Does context determine form? Organisational Dynamics, 1(4), 19-34. https://doi.org/10.1016/ S0090-2616(73)80021-X

PwC (PricewaterhouseCoopers). (2010). Executive remuneration in need of a major makeover. PwC: 1-3, 23 July. Retrieved from http://www.pwc.com/za/en/pressroom/

PWC. (2018). Executive directors' practices and remuneration trends report. Retrieved from https://www.bbrief.co.za/content/uploads/2018/07/Executive-directorsPractices-and-remuneration-trendsreport-2018.pdf

Saunders, M., Lewis, P., \& Thornhill, A. (2007). Research methods for business students (4th edn.). Harlow: Financial Times, Prentice Hall.

Saunders, M., Lewis, P., \& Thornhill, A. (2012). Research methods for business students (6th edn.). Harlow: Pearson

Scholtz, H.E., \& Smit, A. (2012). Executive remuneration and company performance for South African companies listed on the Alternative Exchange (AltX). Southern African Business Review, 16(1), 22-38.

Schuitema, J. (2010). Executive pay revised. Moneyweb. Retrieved from http://www. moneyweb.co.za/archive/executive-pay-revisited/

Shackleton, C. (2007). Developing key performance indicators for corporate communication in the information technology industry. MCom dissertation. Pretoria: University of Pretoria. Retrieved from http://hdl.handle.net/2263/24722

Sigler, K.J. (2011), CEO compensation and company performance. Business and Economic Journal, 31(1), 1-8.

Simon, H. (1957). Models of man: Social and rational. New York, NY: Wiley.

Staff writer. (2017). How much you could earn based on your level of education in South Africa. Businesstech. Retrieved from https://businesstech.co.za/news/ finance/149531/how-much-you-could-earn-based-on-your-level-of-educationin-south-africa/

Strober, M.H. (1990). Human capital theory: Implications for HR managers. Industrial Relations 29(2), 214-239. https://doi.org/10.1111/j.1468-232X.1990.tb00752.x

Sullivan, G.M. (2012). FAQs about effect size. Journal of Graduate Medical Education, 4(3), 283-284. https://doi.org/10.4300/JGME-D-12-00162.1 
Sun, S.L., Zhao, X., \& Yang, H. (2010). Executive compensation in Asia: A critical review and outlook. Asia Pacific Journal of Management, 27(4), 775-802. https://doi. org/10.1007/s10490-010-9207-7

Thalheimer, W., \& Cook, S. (2002). How to calculate effect sizes from published research: A simplified methodology. Somerville, MA: A Work-Learning Research Publication (No. 1, pp. 1-9). Retrieved from http://www.docstoc.com/ docs/47860289/How-to-calculate-effect-sizes-from-published-research-Asimplified-methodology

Trevor, J. (2011). Can pay be strategic? A critical exploration of strategic pay in practice. London: Palgrave Macmillan.

Trusty, J., \& Niles, S.G. (2004). Realized potential or lost talent: High school variables and bachelor's degree completion. Career Development Quarterly, 53(1), 2-15. https://doi.org/10.1002/j.2161-0045.2004.tb00651.x
Van Essen, M., Otten, S., \& Carberry, E.J. (2012). Assessing managerial power theory: Meta-analytic approach to understanding the determinants of CEO compensation. Journal of Management, 41(1), 164-202. https://doi. org/10.1177/0149206311429378

Wallace, M., \& Fay, C. (1983). Compensation theory and practice: Kent human resource management series. Boston, MA: Kent.

Ward, R.M. (2002). Highly significant findings in psychology: A power and effect size survey. Dissertations and Master's thesis (Campus Access). Paper AAl3053127. University of Rhode Island. Kingston: Digital Commons Network. Retrieved from https://digitalcommons.uri.edu/dissertations/AAl3053127

Wilkinson, L., \& APA. (1999). Task force on statistical inference. Statistical methods in psychology journals: Guidelines and explanations. American Psychologist, 54(8), 594-604. https://doi.org/10.1037/0003-066X.54.8.594 